\title{
In Search of Empowerment: Shirley Clarke's Portrait of Jason and Cheryl Dunye's The Watermelon Woman ${ }^{1}$
}

\author{
Maria Anita Stefanelli*
}

\begin{abstract}
American filmmaker Shirley Clarke, in search of empowerment in the male-dominated world of cinema, challenged the racist and homophobic America of the 1960s with her pseudodocumentary (Portrait of Jason, 1967). This centered on a homosexual black man, Jason Holliday, who dreams of a nightclub act as a way of attaining success as a performer. The $16 \mathrm{~mm}$ indie film was forgotten for forty-six years until its 2015 success at the Berlin Film Festival. Over thirty years (1999) after Portrait of Jason was shot, American filmmaker Cheryl Dunye, a black lesbian who both represents and acts herself on screen, searched for archival material that might empower women actresses of the past by recovering their names and personalities. She thus shines some light on the "stories that have never been told", of those queer black actresses usually limited to stereotyped roles as mammies and perhaps not even credited in the movie. Both Clarke and Dunye present us with the small world that emerges from these hidden lives. Thanks to their art, both filmmakers were empowered; for the former, however, this happened too late.
\end{abstract}

\section{Keywords}

women; film; filmmakers; black culture; homosexuality; archives; empowerment.

It is the Sixties: "There is a feeling in the air that cinema is only just beginning" (Film Culture Editors 11). Such a "beginning" was identified with cinema vérité, known in France as a style of documentary filmmaking whose pioneer was French director Jean Rouch. As an anthropologist, Rouch was interested in the ethnographic quality of the conceptual framework of the films he directed, among which is the seminal Moi, un noir (1958), released for English-speaking countries as I, a Negro.

\footnotetext{
*Dipartimento di Lingue, Letterature e Culture Straniere, Università Roma Tre, via del Valco San Paolo, 19 - 00146 Roma, ITALY

Email: mariaanita.stefanelli@uniroma3.it
}

The film focuses on a Nigerian immigrant in Abidjan, the Ivory Coast: it casts nonprofessional actors (some of them using a pseudonym), is shot with a $16 \mathrm{~mm}$ camera, uses nonsynchronous sound (due to the failure of the camera to provide sound and images simultaneously), and experiments with "jumpcuts" in the editing process. ${ }^{2}$ The film ushered in the French New Wave movement, which was reinterpreted in the United States as New American Cinema, "a movement of feature-length, lowbudget narrative films that ran against the grain of commercial filmmaking" (Suarez 40). John Cassavetes launched the movement - "an inheritor of the ideology of the Beat poets and writers and of the underworld of bebops and hipsters" (41) - in the States with Shadows (1959), an independent improvisational film exploring racial discrimination and interracial relations.

Not subject to the Hollywood industry and its time restrictions, or to the control of studio distribution, independent films mostly tackled political and social questions, such as discrimination and social representation, or topics that were held to be scabrous such as alternative sexualities and drug-addiction. The discussion of racial matters, which provoked acrimony and negative reactions among the conservative classes, was embraced by the left wing, the young, and the intellectually enlightened; indeed, the issue became a key element in film studies, and attracted several black students to university film programs (Snead 115). Black filmmakers' interest in "recoding black skin on screen and in the public realm by revising the contexts and concepts with which it had long been associated" (115) answered the desire of their black students', and of black members of the audience, to see their identity represented and honored. As time passed, the idea of assimilation and integration gave way to black self-awareness and sensibility, which informed the following decade (Brigham in Curry 93-94). 
Women's cinema broke with patriarchal conventions in the filming of women and the stories that concerned them. As Judith Mayne puts it, "The development of feminist film theory and criticism in the United States has been shaped by three major forces, all of which are, like feminist film theory itself, phenomena of the late 1960s and early 1970s: the women's movement, independent filmmaking, and academic film studies" (83). A mordant critique addressed stereotyped images of women in the cinema, particularly Hollywood cinema; documentary feminist films inspired by independent filmmaking tackled feminist issues in such a way that political consciousness was raised, while developments in film studies stimulated women to question the very image of woman (84). On the other hand, the question of "female authorship," deriving from the debate on the meaning and function of auteur in France, was ambiguously received at the time. ${ }^{3}$ Issues such as "the auteur theory" and "the film director is" [or isn't] "the single force responsible for the final film," could [or might not] be interpreted according to the "famous equation of the camera with a writer's pen" as a "denial of the possibility of any female agency" (94), became the order of the day, and threatened the public and critical success of a film.

As far as racial matters were concerned, African-American issues re-surfaced in movies where cultural stereotypes about black people abounded, but now there were also characters who were "hip, powerful, rebellious, and sexually active directly [defying] Hollywood's stereotypes of black men as asexual servants and yes-men," and offering glimpses of a new reality (Covey 3 ). One reality that had been covered up, or ignored, until then was that of people with both a "black and queer" identity. In the Sixties and through the Seventies such cinema images tended to be those of the "sad, lonely, "deviant" homosexual on the fringe" (Pincheon 154).

Shirley Clarke (1919-1997), a white privileged woman of an affluent Polish-Jewish background, stands out as an independent female filmmaker who produced a number of films about the events in black people's lives in urban Sixties America. A biographical sketch written for The New York Times at the time of the restoration of the first of these films, an adaptation from Jack
Gelber's play that Clarke produced after seeing Judith Malina's staging of it at The Living Theater on $14^{\text {th }}$ Street earlier in the year, reads as follows:

"Dancer bride, runaway life, radical filmmaker and pioneer - Shirley Clarke is one of the great undertold stories of American independent cinema. A woman working in a predominantly male world, a white director who turned her camera on black subjects, she was a Park Avenue rich girl who willed herself to become a dancer and a filmmaker, ran away to bohemia, hung out with the Beats and held to her own vision in triumph and defeat." (Dargis 2012 online)

In another article, the journalist mentions some equipment Clarke lent to Cassavetes, "bankrolled by family, friends and strangers," to work on the improvisational film on interracial relations that would launch his career (Dargis 2004, 2012, and Baumgarten, all online). An instance, that is, of her personal involvement with the group of filmmakers that was working on independent productions. She was a supporter of African American filmmaker Madeline Anderson, who said of herself, "I filmed history in the making, and it was an honor," and of Clarke, "Shirley was one tough lady whose values and humanity was what... I know a lot of people disapproved of her" (Martin 89).

Just as Clarke turned her shoulders to her own social environment, she also made friends with people she "did not at all resemble, at least sociologically - the beat poet, the jazz musician, the black junkie queen" (Gustafson, 1977, 2). After her marriage with Bert Clarke, to escape her father and devote her talent to dance, that ended in divorce, she had a long romantic relationship with African American black actor, Carl Lee - Cowboy in The Connection - that lasted until his death. On her private-and-professional choices, she commented in 1976: "For years l'd felt like an outsider, so I identified with the problems of minority groups. I thought it was more important to be some kind of goddamned junkie who felt alienated rather than to say I am an alienated woman who doesn't feel part of the world and who wants in." ${ }^{4}$

In 2008 Milestones Films started an archival research with the purpose of restoring her 
films. "Project Shirley," which comprises four volumes - The Connection (1961), Robert Frost: a Lover's Quarrel with the World (1963), Portrait of Jason (1967), and Ornette, Made in America (1984) - was completed in 2016. All, except the one on Frost, focus on black culture, as does The Cool World (1963), a piece on black street stories shot in Harlem. The last of the Sixties' productions has been the most provocative and the most provoking. To Rabinovitz, it is "an insightful exploration of one person's character while it simultaneously addresses the range and limitations of cinema-verité style." An interview made in 1985 at the Chelsea-Hotel in New York City, where Clarke had been producing her video work since the Seventies, reveals her attitude at things feminine or feminist:

"I like to see feminist films, but I've never been able to make one";

"I prefer to be in the anthologies of filmmakers: between René Claire and René Clemont is Shirley Clarke. What I'm saying by that is that I want to be identified with the body of filmmakers, not just women. What will really help women is if they show up everywhere";

"Classifying the kinds of women's films that are being made and analysis [are] needed. We need to take ourselves seriously. Even things as basic as: what is women's consciousness? It has to be politicized. It has to be historical. There are certain biological facts. Women do give birth, but I think when a man puts out his sperm he's also giving birth. The main differences are cultural. In an intrinsic human way, there are very few differences between men and women. It has nothing to do with whether you can lift a brick. None of this matters anymore";

"My images are not feminine images or masculine images, they are general political concepts. But I have a theory about the coming world, the future millennium. If creatures exist, the choice will not be the man. Man does not have the endurance. He won't be necessary. He's the expendable one. Stash a whole bunch of sperm somewhere and go on for the next fifteen hundred years."

(Hallek 1985, online)

From the interview one realizes that, in order to be empowered in a profession that rewarded only men, Clarke's social consciousness suggested that she did not need to choose between playing a female or a male role, but that her work would need to make a political and cultural difference. In Portrait of Jason she acts out her differences while her character acts out his own: she plays the man-director, he the womanactress. That is enough to expose the limits of cinéma verité.

Jason Holliday is, in real life, a friend of Lee's father, the actor Canada Lee. Unasked, he would appear at Clarke's place to help with domestic work and earn some money for "his nightclub act." Sometime later, as Clarke tells her interviewer, she bumped into him and revealed her idea: "I'd like to film you doing what you do, telling those stories you tell and talking about your life". Her partner Lee would question him, while her role would be that of "white lady director" (Rabinovitz 1983, 10-11) and off-screen interlocutor. The film starts and Jason, the onetime "houseboy" turned hustler, performs through "every story" and "every variation" (11), through being his own self and impersonating female stars, through recollection and quotation the narrative of his life. Overall, twelve hours filming at the Chelsea hotel came down to roughly an hour and forty-five minutes after editing. Clarke reflected on her experience as director:

"An interesting and important fact is that I started that evening with hatred, and there was a part of me that was out to do him in, get back at him, kill him. But as the evening progressed, I went through a change of not wanting to kill him but wanting him to be wonderful. Show him off. I went through getting to love him as I spent months sitting at my editing table trying to decide which half of what I filmed I was going to drop. I developed more and more of a total ability to understand where he was coming from - leaping cultural gaps, his homosexuality, his opportunism, his hype. I changed a lot of judgmental ideas by really getting to know Jason."

There is verbal aggression towards Jason on the part of the film crew. He "has been laying himself bare," the interviewer adds, "except you don't know if it's real or if he's performing" (11); then, Clarke:

"He cries, and then in the middle of his sobbing, he turns it off. I tried to make a good ending, but each time I thought it was over, he 
would pull back and do another trip on us: "I'm not lying." "Yes I am." You're right, and we are left with nothing else except that particular reality which happens to be Jason." (11)

The Sixties was a time when homosexuality was a crime: "To be black and gay meant a life on the margin of the margins" (Westphal online). Secondwave feminism, however, though divided along the lines of race and sexuality, offered new ways of thinking about the struggle for black freedom. Film theory, on the other hand, followed the revival of women's studies, and instilled in cinemagoers a tendency to reflect on gender and power within the patriarchal structure of society. With homosexuality being something that even the person involved did not have clear ideas about, Portrait of Jason was among the first to promote the notion of LGBTQ culture. Jason was bold enough to expose his sexual identity, and fight to enforce the reality of it; Shirley had the intelligence to record his dramatic outpouring and believe in her character's survival. In the end, as a human being, he triumphed; his director, unfortunately, did not. Though the film was eulogized as an important product of the New York avant-garde (by Bergman, Ginsberg, and others), and Jason attracted Gilles Deleuze's attention for his style of fabulation that provides it with "political" validation (Ning'o, online), Clarke was eventually "written out of histories and dismissed as a dilettante" (Dargis 2012, online).

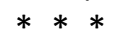

Thirty years later, and another independent filmmaker, black director Cheryl Dunye, risked ruffling people's feathers - to borrow New York Times reviewer Stephen Holden's figure of speech - with the politics of gender in her film The Watermelon Woman (1996). "A hybrid of autobiography, documentary, comedy, and meta-narrative, it was a landmark of New Queer Cinema and the first feature film directed by an African American lesbian" (Kelsey, 2016, online), reads a report of its $2 \mathrm{~K} \mathrm{HD}$ restoration on its $20^{\text {th }}$ anniversary. Alexandra Juhasz, Dunye's partner at the time, was the producer; photographer Zoe Leonard created the fictional archive of the documentary photos, an artwork that provides visibility for what was invisible and has functioned independently from the movie; the author's own relationships were involved in this undoubtedly artful production. The title comes from Melvin Van Peebles' The
Watermelon Man, a story by Herman Raucher about a white insurance salesman who wakes up one morning to find that he has become black. From white identity to a black identity. Dunye uses her own version of the entitlement as "another way to talk about race" (Kelsey, 2016, online). She does so from a feminist viewpoint that coincides with Mark Reid's claim that black films focus on the black community, and are written, directed, produced, and distributed, of necessity, by black filmmakers. He also appeals to Teresa de Lauretis to support his argument for a "genderclass-race analysis that also examines black films in relation to its political and cultural context in African-American history" (Reid 3); hence the word "feminist" used as one of the qualifiers of his cinematic critique (3). With humor and grace Dunye focuses on real and fictional identity; the representation of identity; the expectation or disbelief of a gender identity; the acknowledgement or refusal of a gender identity; the entitlement or repression/denial of a racial identity; and finally, reciprocal interracial desire.

The irony that runs through the film draws attention to the various aspects of identity that are left unresolved. The director's search is an inquiry into these aspects, while the fictional director (the real director is cast as a film director in the movie), who works in a video store, sets out to make a film about a Thirties black actress who played the stereotypical black woman's role; the mammy. This woman with "something interesting, something serious" in her face is not credited by name but is simply referred to as "the Watermelon woman"; she shares, in fact, the destiny of several other black actresses, whose "stories have never been told" (as we can hear at the beginning of the film, The Watermelon Woman).

The fictional Cheryl Dunye digs into the archives in search of all possible biographical details of the fictitious queer black actress who tends to her missy in Plantation Memories, a longforgotten film on slavery. Through the protagonist's historical library and repository research, a complex intersecting of social, gender, racial, and class identities is revealed, which addresses issues of social inequality, discrimination, and oppression. A name, finally, emerges: the actress and singer is called Fae 
Richards, who, Cheryl discovers, worked, and had an affair with white director Martha Page.

The dynamics of intersectional issues develops diachronically in The Watermelon Woman, also thanks to "the search for the (fore) mother" - as Frann Michel (2007, online) puts itthat "drives the protagonist" to iconize black womanhood (and thus the stereotypical elderly black fat mammy) as the "grandmother" figure. In order to support her claim, Dunye interviews distinguished cultural critic Camille Paglia, who, far from stigmatizing the watermelon as the "signifier of racist representation alluded to in the film's title," professes her "love for the mammy figure [...] who reminds her of her Italian grandmother." She thus exposes her "critique of oppressive essentialist stereotypes operating in the academic discourse" (Mazur, 2013, 78). Synchronic intersections, on the other hand, are at work in the cinematic gaze that reworks the conventional patriarchal gaze into a multitude of possibilities, the foremost being the black lesbian perspective within a wider spectrum of gender, race, class, age, and even body shape or size (Mason 2017, 51). All in all, the final product can work as "a powerful medium to catalyse social change" (Kaur, 2017, 22), in keeping with the idea of cinema as a weapon to demolish stereotypes and taboos as expressed in this year's first issue of the Amity Journal of Media \& Communication Studies. However, a critique in a germinal text by race theorist Kimberlé Williams Crenshaw et al. published twenty-eight years ago and reiterated in a 2013 article, makes it clear that "a particularized intersectional analysis or formation is always a work-in-progress, functioning as a condition of possibility for agents to move intersectionality to other social contexts and group formations" ${ }^{\prime 5}$ (303). If the next move in intersectionality theory is to reconceptualize identities in coalitional terms, then let us bear in mind that "[f]ocusing on the self, on its wholeness, provides a major impetus for individual and collective empowerment." (Collins, 2016, 135).

As an African-American lesbian, Dunye has revisited the 'local' - developing into 'universal' memory and has peopled it with the female artist's female ancestors, as well as the female members of the audience, reuniting them to form a collective multifamily community within which all marginalized characters and identities can be at home and not feel rejected. In this type of extended family there is no room for privileged members, not even - since we are focusing on cinema - for a privileged gaze that assumes a male director or spectator and makes women the objects of the male director's or even the spectator's gaze. If we think of English critic Laura Mulvey's critique of the male gaze in her muchquoted essay, Visual Pleasure and Narrative Cinema (1975), we can easily interpret Dunye's work as an intention to unscrew the locks from the doors of all marginalized people's homes in order to free them from the dominant mainstream wielding of power.

Much of what is problematized in the film remains open to further discussion. The pairing, for example, of the black director Cheryl with the white and rich beautiful idler Diana, recalls the discovered relationship between the actress Fae and her director Martha Page. According to Mark Winokur, while the text represents "a desire for wholeness," it highlights the project of integrating "the filmmaker and her on screen persona," and also "the filmmaker and the possibility of making films" (2001, 243, 235). It also integrates the biological with the social, the actual and the metaphorical, the documentary with the fantastic, history and fiction. Brutality and violence are excluded from this richly multifaceted film. It is an all-female world where women's empowerment is not only possible, but just as natural as men's empowerment in the different world that we inhabit. "Engaging with the past and present histories of African-American women's experiences," writes Michel, "reveals both the permeability of borders and the power of creative transgressions" (2007, online). Could such bordercrossing work at all levels, and resistance to boundaries become assistance, compliance and cooperation?

Portrait of Jason and The Watermelon Woman endow two representatives of humanity in different ways, providing unforeseen visibility. For different reasons, the two films would not be the same without the "lack of control" that derives from the editing of the work. An alternative editing technique might have removed certain psychological aspects: for instance, important Freudian slips, "those accidental errors, which 
result from momentary loss of control over language, where we would normally edit or entirely edit out the undesirable (suppressed) content" (Mazur, 2013, 77). Whether we hear what we wouldn't like to hear (like Clarke's and Lee's racist comments in Portrait of Jason), or we are caught within a non-functional digression (like the interviewees staring back to Dunye's camera in The Watermelon Woman), we are being shown different stories or fragments of different stories that would otherwise be lost. What is underneath may be just as interesting as what is on the surface.

Both Shirley Clarke and Cheryl Dunye present us with a small world that works within these differences.

\section{References}

Baumgarten, M. 2012, 'From the Vaults: When Shirley Clarke Met Roger Corman', The Austin Chronicle. Oct. 12 Web, July 30, 2017, <https://www.austinchronicle.com/daily/screens/201 2-10-12/from-the-vaults-when-shirley-clarke-metroger-corman/>

Bordwell, D., Thompson, K. 2006, Film Art: An Introduction, New York: McGraw Hill.

Brigham, W. 1996, "Whatup in the 'Hood? The Rage of African American Filmmakers." In States of Rage: On Cultural Emotion and Social Change, Eds. R. R. Curry and T. L. Allison. New York: New York U.P. pp.91-106.

Collins, P.H., and Sirma, B. 2016, 'Intersectionality', Cambridge, UK: Polity Press.

Covey, W. 2003, 'The Genre Don't Know Where It Came From: African American Neo-Noir Since the 1960s' Journal of Film and Video, vol. 55, no.2-3. Summer/Fall, pp.59-72.

Crenshaw, K.W. 1989, 'Demarginalizing the Intersection of Race and Sex: A Black Feminist Critique of Antidiscrimination Doctrine, Feminist Theory and Antiracist Politics', The University of Chicago Legal Forum, pp.139-67.

Crenshaw, K.W. 1991, 'Mapping the Margins: Intersectionality, Identity Politics, and Violence against Women of Color', Stanford Law Review, vol.43, pp.1241-1299.

Dargis, M. 2004, 'John Cassavetes, Laughing Last', The New York Times, September 26 online Web, July 30, 2017,

<http://www.nytimes.com/2004/09/26/movies/johncassavetes-laughing-last.html>.

Dargis, M. 2012, 'Woman with a Lens, Restored', The New York Times, April 29 online Web, July 30, 2017, <http://query.nytimes.com/gst/fullpage.html?res=980 DE1DC1438F93AA15757C0A9649D8B63\&pagewanted =all>
Carbado, D.W., K.W. Crenshaw, V.M. Mays, and B. Tomlinson (2013), "INTERSECTIONALITY. Mapping the Movements of a Theory," Du Bois Review 10.2 (Fall): pp. 303-12.

Gustafson, Irene. 1977, 'Putting Things to the Test: Reconsidering Portrait of Jason', Camera Obscura, vol.6, pp.1-31.

Hallek, D. 1985, 'Interview with Shirley Clarke', The Early Video Project Web, July 30, 2017, <http://davidsonsfiles.org/index.html>

Holden, S. 1997, 'On Black Films and Breezy Lesbians', The New York Times, March 5, 1997 Web, July 30, 2017, <http://www.nytimes.com/movie/review?res=9C04E2 DD1430F936A35750C0A961958260.

Kaur, P. 2017, 'Gender, Sexuality and (Be) longing: The Representation of Queer (LGBT) in Hindi Cinema', Amity Journal of Media \& Communication Studies, vol.7, pp.22-30

Kelsey, C. 2016, 'Cheryl Dunye's Alternative Histories', Interview, November 11 Web, July 20, 2017, $<$ https://www.interviewmagazine.com/film/cheryldunye\#.

Martin, M. 2013, 'Madeline Anderson in Conversation: Pioneering an African American Documentary Tradition', Black Camera, An International Film Journal 5.1 Fall, pp.72-93

Mason, C. 2017, 'Queering the Mammy: New Queer Cinema's Version of an American Institution in Cheryl Dunye's The Watermelon Woman', Black Camera: an International Film Journal, vol.8, pp.50-74.

Mayne, J. 1990, 'The Woman at the Keyhole Feminism and Women's Cinema', Bloomington: Indiana U.P.

Mazur, K. 2013, 'The Watermelon Woman and Black Queer Cinema', in A. M. Różalska, and G. Zygadło, eds., Narrating American Gender and Ethnic Identities, Newcastle upon Tyne: Cambridge Scholars Publishing, pp.73-91.

Michael, F. 2007, 'Eating the (M)Other: Cheryl Dunye's Feature Films and Black Matrilineage', Rhizomes, no. 14 Web, July 30, 2017, <http://www.rhizomes.net/issue14/michel/michel.ht ml>.

Mulvey, L. 1975, "Visual Pleasure and Narrative Cinema", Screen, vol.16, no. 3, pp.6-18.

Ning'o, T. 2015, 'Jason and Shirley: Restoring an Underground Star's Lost Honour', The Guardian. International Edition, 19 September Web, July 20, 2017, $<$ https://www.theguardian.com/film/2015/sep/19/jas on-and-shirley-restoring-an-underground-stars-losthonour>

Pincheon, BS. 2001, 'Black and Queer Visual Culture: An Annotated Filmography and Reference Guide', The Moving Image: The Journal of the Association of Moving Image Archivists, vol.1, pp.151-97.

Powers, J. 2013, 'Peeling Away the Layers in 'Portrait of Jason', Fresh Air, May 2 Web, July 20, 2017, < 
https://www.npr.org/2013/05/02/179876018/peeling -away-the-layers-in-a-portrait-of-jason>

Rabinovitz, L. 1983, 'Choreography of Cinema: An Interview with Shirley Clarke', Afterimage, December, pp.8-11 Web, July 20, 2017 $<$ http://www.vasulka.org/archive/430c/AfterlmageDec83(300).pdf>

Rabinovitz, L. 1991, Points of Resistance: Women Power and Politics in the New York Avant-garde Cinema 194371, Urbana, Chicago: University of Illinois Press.

Read, M. A. 1993, 'Redefining Black Film', U. of California Press.

"Shirley Clarke - Director" Film Reference Web, January 17, 2018, <http://www.filmreference.com/DirectorsBu-Co/Clarke-Shirley.html>

Snead, J., MacCabe C. and West C. 1994, 'White Screens/Black Images: Hollywood from the Dark Side', New York: Routledge.

Suárez, JA. 2007, Jim Jarmusch, Urbana, Chicago: U. of Illinois $P$.

"Third Independent Film Award", Film Culture nos. 2223, Summer 1961, p.11.

${ }^{1}$ I am very grateful to Professor Adrian Perez Melgosa (Stony Brooke University) for bringing Cheryl Dunye's The Watermelon Woman to my attention.

${ }^{2}$ This technique consists of two sequential shots of the same subject taken from slightly different camera positions, and gives the effect of jumping forward in time and space (Bordwell and Thompson 254).

${ }^{3}$ For a discussion of the question of cinema authorship following the heated debate in France on the auteur of the film and the development of the notion up to today, see the chapter "Female authorship reconsidered" (Mayne 89-123).

${ }^{4}$ The quotation is from projectshirley.com.

5 Crenshaw published, with other authors, "INTERSECTIONALITY. Mapping the Movements of a Theory." The essay followed "Demarginalizing the
Westphal, K. 2013, 'The Anti-Restoration of Portrait of Jason: A Conversation with Dennis Doros', The Chicago Film Society, May 28 Web, July 20, 2017.

Winokur, M. 2001, 'Identifying with the (Black) Lesbian Body in Cheryl Dunye's The Watermelon Woman," in M. Bennet and V.D. Dickerson, eds,' Recovering the Black Female Body. Self-Representations by African American Women, New Brunswick: Rutgers U.P., pp.231-52.

Intersection of Race and Sex: A Black Feminist Critique of Antidiscrimination Doctrine, Feminist Theory and Antiracist Politics" (1989), and "Mapping the Margins: Intersectionality, Identity Politics, and Violence Against Women of Color," where intersectionality is advocated to elide the vulnerability of women of color from immigrant and socially disadvantaged communities (1991). 